\author{
ANITA KulaWIAK \\ Uniwersytet Łódzki, Polska \\ University of Lodz, Poland
}

\title{
Rola i znaczenie placów targowych w dużym mieście. Przykład Łodzi
}

\section{Role and Significance of Marketplaces in a Large Town - the Example of Łódź in Poland}

\begin{abstract}
Streszczenie: Obecnie pod znakiem zapytania stoi dalsze funkcjonowanie targowisk w miastach, co ma związek zarówno z intensywnym rozwojem handlu wielkopowierzchniowego, wypierającego tę tradycyjną formę handlu, jak i z zawłaszczaniem tej przestrzeni przez władze miejskie na inne, pozahandlowe cele. Jednocześnie dla wielu mieszkańców miast targowiska nadal odgrywają ważną rolę, przede wszystkim jako miejsca dokonywania codziennych zakupów. W kontekście zaobserwowanych nieścisłości badawczych w artykule podjęto problem identyfikacji roli targowisk we współczesnym mieście. Podstawę teoretyczno-metodologiczną badań stanowi koncepcja funkcji miejsca A. Suliborskiego (2001). Jej zastosowanie pozwoliło na uchwycenie zarówno roli użytkowej, jak i społecznej targowisk. W artykule wykorzystano metody kameralne i terenowe, w tym wywiad kwestionariuszowy, który przeprowadzono na grupie 200 mieszkańców Łodzi.
\end{abstract}

\begin{abstract}
Currently, the further functioning of marketplaces in towns is in question. This is related to both the intensive development of large-scale trade, displacing this traditional form of trade, and the appropriation of this space by the town authorities for other, non-commercial purposes. At the same time, however, for many inhabitants marketplaces still play an important role, mainly as a place to shop every day. In the context of observed research inaccuracies, the article deals with the problem of identifying the role of marketplaces in a modern town. The theoretical and methodological basis of the undertaken research is the concept of the function of a place of A. Suliborski (2001). Using said concept allowed for investigating the utility and social role of marketplaces. The article uses various research methods: study and field methods including a questionnaire interview that was carried out on a group of 200 Łódź residents.
\end{abstract}

Słowa kluczowe: funkcja miejsca; geografia społeczna; Łódź; targowisko Keywords: function of a place; Łódź; marketplace; social geography

Otrzymano: 3 stycznia 2020

Received: 3 January 2020

Zaakceptowano: 21 kwietnia 2020

Accepted: 21 April 2020

Sugerowana cytacja/ Suggested citation:

Kulawiak, A. (2020). Rola i znaczenie placów targowych w dużym mieście. Przykład Łodzi. Prace Komisji Geografii Przemysłu Polskiego Towarzystwa Geograficznego, 34(3), 86-101. doi 10.24917/20801653.342.6 


\section{WSTĘP}

Plac targowy od zawsze stanowił nierozerwalną część polskich miast, pełniąc przy tym wiele bardzo ważnych funkcji. Jego podstawową działalnością było zaopatrywanie mieszkańców w produkty żywnościowe, ale poza handlem istotną rolę odgrywał on też w tworzeniu charakteru miasta, a nierzadko i samego miasta. Jako że najczęściej targowiska lokowane były w centrach miast, stanowiły też główne miejsce w osadzie, wokół którego, koncentrowało się życie publiczne i polityczne - odbywały się tam ważne zebrania, uroczystości, jak i życie codzienne mieszkańców. Jak pisze E. Przesmycka, „tutaj dochodziło do transakcji handlowych, ale poza tym można było poprzyglądać się tłumom, spędzić czas na biesiadowaniu z przyjaciółmi i być uczestnikiem ogólnodostępnych rozrywek" (Przesmycka, 2008: 78). Na przestrzeni wieków funkcje oraz znaczenie placów targowych zmieniały się, ale aż do czasów gospodarki rynkowej ich rola w przestrzeni miast nadal pozostała znacząca. Zwracają na to uwagę m.in. M. Płaziak i A. Szymańska, według których w czasach gospodarki centralnie sterowanej były one ważne dla mieszkańców, dając sposobność zakupu towarów niedostępnych w miejscowych sklepach. Znaczenie ich nie zmniejszyło się również po 1989 roku, kiedy to w okresie transformacji ustrojowej i społeczno-gospodarczej, która to przyczyniła się do przekształceń funkcji handlowo-usługowych, place targowe uległy przeobrażeniom, wraz z pojawiającymi się nowymi przedsiębiorcami i oferowanym przez nich nowym asortymentem (Płaziak, Szymańska, 2014: 90).

Współcześnie opinia wielu autorów na temat roli i znaczenia tych przestrzeni w mieście jest wyraźnie podzielona. Część badaczy twierdzi, że przestrzenie te, na skutek przede wszystkim budowy wielkich centrów handlowych, prężnego rozwoju nowych form dystrybucji (sklepy internetowe), a także dokonujących się nieustannie zmian w zachowaniach nabywców, istotnie tracą na znaczeniu, a nawet przeżywają swoisty kryzys (Zuzańska-Żyśko, Sitek, 2011; Sławińska, 2014; Bieszk-Stolorz, Felsztyńska, 2018). Jako dowód często przytacza się dane GUS, z których wynika, że od 2003 roku systematycznie zmniejsza się powierzchnia targowisk w Polsce, podczas gdy liczba sklepów wielkopowierzchniowych wzrasta (Bieszk-Stolorz, Felsztyńska, 2018). Inni z kolei (Płaziak, Szymańska, 2014; Hamulczuk, 2016; Malinowska, 2016; Płaziak, Szymańska, 2016a) są zdania, że przestrzenie te nie tylko nie ulegają degradacji, ale wręcz się rozwijają, o czym świadczy m.in. zwiększająca się ich różnorodność asortymentowa, a także liczba dni targowych.

Jak piszą M. Płaziak i A. Szymańska: „Współcześnie większość placów targowych działa codziennie. Zwiększa się różnorodność asortymentowa, nie tylko rolnicy sprzedają na nich swoje płody rolne, a rzemieślnicy swoje wyroby, ale coraz częściej na terenie placów targowych znajdują się stałe, zadaszone stragany lub hale ze stoiskami, a także małe sklepy, w których handel jest prowadzony niekoniecznie przez właścicieli lub najemców obiektów, ale również przez pracowników" (Płaziak, Szymańska, 2016a: 219). Ponadto w literaturze nie brakuje także opinii, że odgrywają one istotną rolę w pobudzaniu lokalnej przedsiębiorczości i miejsc pracy, a zatem pozytywnie oddziałują również na rozwój społeczno-gospodarczy (Hamulczuk, 2016; Sojkin, Michalak, 2018).

W kontekście zaobserwowanych w literaturze różnic w postrzeganiu roli targowisk we współczesnym mieście w artykule podjęto problem jej identyfikacji na przykładzie wybranych targowisk oraz spróbowano odpowiedzieć na pytanie, czy targowiska są w miastach jeszcze potrzebne. 
Temat ten wydaje się ciekawy szczególnie w kontekście pojawiających się w miastach coraz częściej, z inicjatywy urzędników lub prywatnych inwestorów, pomysłów zawłaszczania lub rewitalizacji tej przestrzeni. Nierzadko place targowe zajmują bowiem obszary o dużych walorach lokalizacyjnych, co rodzi zakusy na ich szybkie skomercjalizowanie ${ }^{1}$. Powstaje jednak pytanie, czy tego typu zmiany są wskazane i uzasadnione społecznie.

\section{CEL I METODYKA BADAŃ}

Głównym celem artykułu jest identyfikacja współczesnej funkcji placów targowych, w tym szczególnie określenie ich roli użytkowej i społecznej. Do realizacji celu wykorzystano trzy najpopularniejsze łódzkie targowiska - Rynek Bałucki, Górny Rynek oraz Zielony Rynek (plac Barlickiego). 0 ich wyborze zdecydowały dwa fakty - po pierwsze, wszystkie cechuje bardzo długa, bo sięgająca jeszcze XIX wieku tradycja związana z funkcją handlową, a co za tym idzie, od początku wywierały one silny wpływ na rozwijające się miasto, po drugie, ich położenie w granicach centrum miasta, czyli w obrębie najstarszej tkanki miejskiej. Sposób ich postrzegania przez mieszkańców, a także identyfikacja pełnionych przez nie aktualnie funkcji gospodarczych zdaniem autorki mogą być wyznacznikiem (barometrem) dokonujących się w tym obszarze zmian.

W warstwie teoretyczno-metodologicznej praca odwołuje się do koncepcji funkcji miejsca, wprowadzonej do literatury przez A. Suliborskiego, w której funkcja rozumiana jest jako korelat czterech jego atrybutów:

- formy architektonicznej i zagospodarowania, w których została zapisana informacja o ich pierwotnym przeznaczeniu i wykorzystaniu,

- eksploatacji (użyteczności), związanej z wykorzystaniem instytucjonalnym miejsca,

- społecznej percepcji, z której wynika subiektywna ocena jego przeznaczenia i roli (funkcji) dla poszczególnych osób i grup;

- społecznego znaczenia, opisywanego stosunkiem ludzi do miejsca, któremu jest nadawana jakaś wartość (Suliborski, 2001; 2010).

Empiryczną podstawę studium stanowiły materiały i informacje zebrane w trakcie badań terenowych przeprowadzonych w 2018 i 2019 roku oraz badań studyjnych. Do ustalenia funkcji użytkowej oraz stanu zagospodarowania placów targowych wykorzystano inwentaryzację terenową, w tym narzędzie w postaci autorskiej karty inwetaryzacyjnej, a także skorzystano z dostępnej na stronie internetowej ewidencji działalności gospodarczej (CEiIDG).

Społeczną funkcję miejsca (postrzegania i wartościowania) określono natomiast za pomocą metody wywiadu kwestionariuszowego, wykorzystując narzędzie w postaci ankiety papierowej. Ankietę przeprowadzono na grupie 200 losowo wybranych mieszkańców Łodzi, którzy w dniu badania byli użytkownikami tych targowisk oraz mieli powyżej 18 lat. Wielkość próby na każdym z badanych targowisk była podobna i wynosiła: na Rynku Bałuckim i Górniaku po - 67 osób, a na Zielonym Rynku - 66. W grupie respondentów przeważały osoby w wieku 35-55 lat (69\%). Charakteryzują się one

1 Przykładem takich działań jest rozpisany w grudniu 2017 roku w Łodzi konkurs architektoniczno-urbanistyczny na rewitalizację Zielonego Rynku, którego celem jest poprawa jakości życia, zamieszkania i korzystania z dzielnicy Polesie, zachowanie i wzmocnienie jej historycznej tożsamości, a także jej szeroko podjęta aktywizacja postrzegana w kontekście całego historycznego centrum Łodzi (Urząd Miasta Łódź, 2019). 
w większości wykształceniem średnim (48\%), w najmniejszym stopniu zawodowym (25\%). Kwestionariusz ankiety zawierał pytania, zarówno otwarte, jak i zamknięte, i dotyczyły one m.in. celów wizyt na targowiskach, pełnionych przez nie funkcji, oceny sposobu ich funkcjonowania, a także stosunku emocjonalnego mieszkańców do wybranych targowisk. Pytania dotyczyły zatem zarówno percepcji tych miejsc, jak i przypisywanego im znaczenia emocjonalnego.

Opisu historii tych miejsc dokonano w oparciu o teksty źródłowe dotyczące historii miasta.

\section{PLAC TARGOWY W LITERATURZE PRZEDMIOTU - DEFINICJA I KIERUNKI BADAŃ}

Przedmiotem badań niniejszego artykułu jest plac targowy. Pojęcie to, z uwagi na jego potocznie zrozumiały charakter jako miejsca, w którym odbywa się handel, a w dawnych wiekach targi, rzadko bywa definiowane w literaturze przedmiotu. Często natomiast używane jest zamiennie $\mathrm{z}$ określeniami takimi jak targowisko czy rynek. W potocznym rozumieniu plac targowy najczęściej kojarzy się z miejscem, na którym sprzedawane są towary przez rolników (producentów) lub handlarzy - pośredników oraz gdzie można się targować (negocjować cenę). Wykorzystywany jest najczęściej przez mieszkańców do zaopatrywania gospodarstwa domowego. Z obszaru miasta w sposób czytelny wyróżnia go specyficzny sposób zagospodarowania (duża liczba położonych blisko siebie straganów, budek, kiosków oferujących głównie świeże owoce i warzywa, sporadycznie odzież) oraz duży natłok kupujących i sprzedających.

W ujęciu urzędowym funkcjonuje natomiast pojęcie targowiska, przez które rozumie się wyodrębnione tereny lub budowle (plac, ulica, hala targowa) ze stałymi, względnie sezonowymi punktami sprzedaży detalicznej lub urządzeniami przeznaczonymi do prowadzenia handlu, codziennie lub w wyznaczone dni tygodnia ${ }^{2}$. W literaturze naukowej plac targowy bywa także zamiennie nazywany targowiskiem, targiem lub placem handlowym i najczęściej jest on utożsamiany z ogólnodostępną powierzchnią wydzieloną na potrzeby handlu (zazwyczaj drobnego), znajdującą się w różnych rodzajach struktury miejskiej.

Plac targowy z uwagi na uniwersalny charakter stanowi przedmiot zainteresowania i zarazem badań wielu dyscyplin naukowych. 0 tym specyficznym i unikatowym rodzaju przestrzeni miejskiej piszą m.in. geografowie, socjolodzy, ekonomiści, urbaniści oraz architekci i historycy, koncentrując jednak uwagę na różnych jego aspektach.

Ujęcie geograficzne nawiązuje do dorobku geografii osadnictwa (miast), dla której podstawową kategorią analityczną jest struktura przestrzenna miast. W związku z powyższym w literaturze geograficznej place targowe rozpatrywane są przede wszystkim w aspekcie funkcjonalnym, w tym szczególnie uwaga badaczy koncentruje się na funkcji, jaką spełniają w strukturze przestrzennej i ekonomicznej miast, w tym także na obszarach przygranicznych (Mydel, 1977; Dziechciarz, 1992a; Werwicki, 2001; Powęska, 2002a, 2002b; Zuzańska-Żyśko, Sitek, 2011; Płaziak, Szymańska, 2014, 2015, 2016a, 2016b). Warto dodać, że ostatnio powstały też pojedyncze opracowania dotyczące atrakcyjności dokonywania zakupów i prowadzenia handlu w tego typu przestrzeniach (Dziechciarz, 1992b; Urban, Michałowska; 2013; Płaziak, Szymańska, 2016a).

\footnotetext{
${ }^{2}$ Zgodnie z definicją Głównego Urzędu Statystycznego.
} 
Podobnie jak geografowie na plac targowy patrzą ekonomiści, przy czym ich uwaga skoncentrowana jest głównie na roli tego rodzaju handlu w gospodarce miast, regionów, czy kraju (Lautor, 1995; Wojdacki, 2011; Szromik, 2014; Hamulczuk, 2016; Malinowska, 2016; Wojdacki, 2016; Sojkin, Michalak, 2018). W szczególności podejmują oni tę problematykę w kontekście rozwoju sektora małych przedsiębiorstw oraz szarej strefy (Tomalak, Wyżnikiewicz, 1999; Ciechomski, 2014).

Nieco inne spojrzenie na targowisko prezentują z kolei architekci i socjologowie. Należy jednak dodać, że zarówno jedni, jak i drudzy traktują te miejsca jako swoistą przestrzeń publiczną. Architekci najczęściej rozpatrują place targowe jako element układu urbanistycznego miasta i analizują je z punktu widzenia praktyki projektowej, w tym głównie pod kątem zagospodarowania, aranżacji, fizjonomii i ich rozplanowania w strukturze miasta (Gołąb-Korzeniowska, 1997; Barek, 2010; Pasiut, 2012). Z kolei socjologowie podejmują przede wszystkim problematykę społecznego funkcjonowania tych miejsc. Dla nich targowisko jest bowiem głównie terenem interakcji społecznych, stąd najczęściej analizują je w dwojaki sposób - jako arenę procesów społecznych lub jako arenę życia codziennego (Bierwiaczonek, Lewicka, Nawrocki, 2012; Derek, 2014).

Nawet pobieżny przegląd polskiej literatury przedmiotu pozwala zauważyć, że temat placów targowych jest ze względu na swoją uniwersalność dość popularnym zagadnieniem badawczym. W podejściu różnych dyscyplin do tej kwestii wyraźnie jednak rysują się dwa odrębne stanowiska (punkty wyjścia). Pierwsze, charakterystyczne głównie dla geografii, ekonomii, architektury, opisuje plac targowy jako efekt (wytwór) działalności ludzkiej, czyli skupia uwagę głównie na jego aspektach (cechach) materialnych (tj. zabudowa, kształt, rodzaj odbywających się tam działalności/funkcji ekonomicznej, konkretnej roli, jaką miejsca te odgrywają w strukturze gospodarczej miast i regionów).

Drugie natomiast, reprezentowane głównie przez socjologię, analizuje tę specyficzną przestrzeń w mieście jako swoistą kategorię społeczną, czyli miejsce mające swoją wartość i znaczenie w świadomości społecznej. Punktem wyjścia są tu zatem niematerialne elementy (cechy) tej przestrzeni (tj. znaczenie, wartościowanie, funkcja/ rola społeczna).

Żadne z tych ujęć, z uwagi na koncentrację tylko na jednym z wyróżnionych elementów, nie pozwala jednak na pełną interpretację i analizę tej specyficznej przestrzeni miejskiej. Na tym tle warto zauważyć, że znaczącą rolę może mieć tu zatem do odegrania geografia społeczna, która ze swej natury jako jedyna dyscyplina jest w pełni predestynowana do całościowego (holistycznego) ujmowania tego zagadnienia i do tego dąży.

Geografia społeczna to bowiem, odwołując się do A. Suliborskiego i M. Wójcika, dyscyplina, która wyjaśnia struktury i procesy społeczne w ich przestrzennym wymiarze (terytorialnym), a w warstwie wyjaśniającej koncentruje się na procesie społecznego tworzenia różnych form środowiska życia ludzi (krajobrazów, regionów, miejsc miast i wsi) i relacjach, które łączą człowieka z otoczeniem (Suliborski, Wójcik, 2014). Tym samym może być ona użyteczna w analizie placów targowych z uwzględnieniem zarówno ich materialnych, jak i niematerialnych elementów. Niniejszy artykuł jest próbą wykorzystania metod i spojrzenia reprezentowanego przez geografię społeczną do analizy wybranych placów targowych Łodzi. 


\section{GENEZA I ROZWóJ ŁÓDZKICH TARGOWISK}

Łódź ma dość długą, bo liczącą przeszło 600 lat, tradycję związaną z handlem targowiskowym. Po raz pierwszy przywilej organizowania targów i jarmarków nadał Łodzi król Władysław Jagiełło jeszcze w XV wieku (1423). Zgodnie z jego decyzją targi odbywały się co środę, ale dodatkowo miasto uzyskało jeszcze prawo do organizacji dwóch tzw. wielkich jarmarków, które odbywały się dzień po świętach religijnych - Bożym Ciele oraz Wniebowzięciu Najświętszej Maryi Panny. Wszystkie odbywały się na Rynku Starego Miasta.

Bardzo intensywny rozwój Łodzi w XIX wieku, a co za tym idzie, i gwałtowny jej rozwój ludnościowy spowodował znaczne zmiany zarówno w liczbie dni targowych, jak i miejsc do tego przeznaczonych. Od 1832 roku targi odbywały się na zmianę zarówno na Starym Rynku, jak i na Rynku Nowego Miasta we wtorki, ale już niecałe 10 lat później dodatkowo na targowisko przeznaczono również rynek bielnikowy fabrycznej osady Łódki, gdzie handlowano w środę. Na skutek wciąż rosnącej populacji Łodzi zwiększono liczbę targów i od 1864 roku w mieście odbywały się już trzy targi w tygodniu: w poniedziałek na Rynku Nowego Miasta, w środę na Rynku Starego Miasta, a w piątek na rynku bielnikowym. Wciąż jednak liczba targów była niewystarczająca, w konsekwencji czego na targowiska zaczęto przeznaczać, obok gruntów rządowych, także prywatne.

Współcześnie żaden z wymienionych powyżej placów nie pełni dziś funkcji handlowej. Aktualnie najbardziej znanymi i najczęściej uczęszczanymi łódzkimi targowiskami są: Górniak (położony w obrębie placu Niepodległości w południowej części miasta), Rynek Bałucki znajdujący się w obrębie dzielnicy Bałuty, w północnej części miasta, Zielony Rynek (plac Barlickiego, znajdujący się w centrum miasta) oraz plac Poznańskiego Czerwca położony na terenie osiedla mieszkaniowego Teofilów. Trzy pierwsze targowiska stanowią przedmiot niniejszych badań. Łączy je podobny okres powstania, a co za tym idzie, wciąż żywa i trwająca niezmiennie od XIX wieku tradycja handlowa. Różni je ścieżka rozwoju, która w przypadku każdego z nich przebiegała nieco inaczej.

\section{Rynek Bałucki}

Spośród wybranych do badań targowisk Rynek Bałucki ma najstarszą genezę. Jego powstanie było konsekwencją wytyczenia w 1818 roku w północnej części miasta traktu łęczycko-piotrkowskiego, który połączył Łódź ze Zgierzem. W jego wyniku dziedzic Łagiewnik przeznaczył północną część wsi Bałuty, będącą wówczas jego własnością, pod zabudowę o charakterze miejskim (Kulesza, Pawłowski, 1985).

Z uwagi na tak dogodne położenie komunikacyjne Rynek Bałucki stał się z czasem najruchliwszym placem handlowym tego zespołu, zwłaszcza w zakresie obsługi okolicznych wsi (Baranowski, Fijałek, Rosin, 1988). Przy rynku zlokalizowano krańcówkę tramwajów podmiejskich, będącą końcem trasy dla chłopów przyjeżdżających do Łodzi z okolicznych wsi: Emilii, Słowika, Wierzbna w celu robienia zakupów w małych, żydowskich sklepikach na Starym Mieście (Spodenkiewicz, 1999). W czasach II wojny światowej plac ten spełniał wiele funkcji. Między innymi założono tu placówkę gestapo, odbywał się przeładunek surowców wykorzystywanych do produkcji na terenie getta 
różnych towarów, żywności oraz lekarstw, a także funkcjonowała poczta. Po wojnie na Rynek Bałucki powrócił handel i w tym początkowym okresie był to głównie rynek zbytu dla towarów z okolicznych wsi. Środek placu przez dziesięciolecia wypełniały zadaszone stoiska, budy i wiaty. Dopiero w 2010 roku zagospodarowanie Rynku Bałuckiego uległo zasadniczej zmianie.

\section{Zielony Rynek (plac Barlickiego)}

Formalnie plac, na którym dziś odbywa się handel targowiskowy, nosi nazwę placu Barlickiego, ale przez łodzian nadal nazywany jest jego dawną nazwą, czyli Zielonym Rynkiem. Plac ten jest przykładem targowiska, które wytyczono na gruntach rządowych, w sposób planowy, na skutek regulacji miasta, którą w tej części Łodzi przeprowadzono w II połowie XIX wieku. Rynek ten wytyczono na terenie nowej dzielnicy zwanej Wiązową u zbiegu ówczesnych ulic Dzielnej i Pańskiej ${ }^{3}$ w latach 1870-1873. Początkowo nazywano go Rynkiem Wiązowym, a później dopiero Zielonym (prawdopodobnie po zmianie nazwy ulicy z Dzielnej na Zieloną). Dzisiejszą nazwę - plac Barlickiego uzyskał dopiero po II wojnie światowej.

Zielony Rynek z zamierzenia miał być rynkiem zbytu dla produktów miejscowego rolnictwa (Koter, 1969). Na skutek jednak intensywnego rozwoju miasta plac ten już od 1890 roku stał się bardzo ruchliwym targowiskiem. Odbywał się tu handel towarami spożywczymi, wyrobami bednarskimi i meblarskimi, a także rozkładano tu namioty cyrkowe. W 1899 roku plac został wybrukowany oraz wyposażono go w studnię głębinową. Znaczenie Zielonego Rynku jeszcze bardziej wzrosło w 1904 roku, po ulokowaniu w jego pobliżu łódzkiego urzędu powiatowego oraz Szkoły Aleksandryjskiej (rosyjskie gimnazjum państwowe). W tym czasie działki wokół placu rozparcelowano i odsprzedano pod budowę kamienic czynszowych oraz domów prywatnych. W okresie międzywojennym we wschodniej pierzei placu powstała, istniejąca do dzisiaj hala targowa, tzw. Stara Hala, w której zlokalizowane były stoiska mięsne. W południowej części placu przez wiele lat mieściła się natomiast krańcówka autobusowa.

Aż do pierwszej dekady XXI wieku wnętrze targowiska wypełniały boksy, stragany, przyczepy oraz dzikie stoiska handlarzy. W 2007 roku targowisko zasadniczo przebudowano. Zamknięto główną płytę handlową, usunięto dzikie boksy, uporządkowano alejki, a także zadaszono całą powierzchnię. Ponadto w miejscu dawnej krańcówki powstała nowoczesna, klimatyzowana hala targowa wyposażona w powierzchnie wystawiennicze, bankomaty i toalety.

\section{Górniak (plac Niepodległości)}

Plac Niepodległości, pierwotnie zwany placem Leonhardta, powstał na przełomie XIX i XX wieku na gruntach prywatnych, należących do przemysłowca E. Leonhardta (stąd też jego pierwotna nazwa). Znajdujący się w jego obrębie targ utworzono 1 kwietnia 1904 roku w granicach dzisiejszych ulic Piotrkowskiej, Wólczańskiej i Sieradzkiej, tj. w południowej części tego placu i zarazem w południowej części miasta. Targowisko

\footnotetext{
${ }^{3}$ W latach sześćdziesiątych XX wieku w zachodniej części miasta wytyczono nowe ulice, które ułatwiały dojazd z okolicznych osad do jego centrum. Stworzono siatkę ulic, wzorując się ściśle na układzie sieci śródmiejskiej. Przedłużono przecznicę ulicy Piotrkowskiej - ulicę Dzielną (Zielona) oraz biegnącą równolegle do osi układu ulicę Pańską (Żeromskiego).
} 
to miało stanowić konkurencję dla rozwijającego się wówczas nieopodal innego targowiska - Górnego Rynku, dziś zwanego placem Reymonta. W dość szybkim tempie zaczęto go zatem zagospodarowywać, czemu dodatkowo sprzyjała także powiększająca się systematycznie liczba ludności miasta oraz położenie w pobliżu linii tramwaju podmiejskiego, która dowoziła ludność z okolicznych wsi (Kowalczyński, 2008).

W rezultacie już w 1905 roku wybudowano tam zadaszone, drewniane stragany, a w 1934 roku pierwszą drewnianą halę targową. Po I wojnie światowej targowisko to całkowicie przejęło handel z Górnego Rynku, łącznie z jego nazwą, do dziś zresztą powszechnie używaną przez łodzian. W czasach gospodarki centralnie planowanej w jego pobliżu uruchomiono krańcówkę tramwajów podmiejskich oraz autobusów, a także wybudowano dom handlowy Uniwersal - największy wówczas w całym regionie łódzkim, co jeszcze bardziej wzmogło jego rozwój. W rezultacie obok Rynku Bałuckiego targowisko to aż do dnia dzisiejszego należy do największych i najczęściej uczęszczanych łódzkich targowisk. Warto dodać, że mimo intensywnego rozwoju targowisko to przez długie lata nie zmieniało swojego wyglądu i zagospodarowania. Znaczącej renowacji i przebudowie plac ten został poddany dopiero 10 lat temu. Dopiero w 2009 roku miejsce drewnianych, prowizorycznych i niezadaszonych straganów zajęły nowoczesne hale targowe.

\section{ZAGOSPODAROWANIE WYBRANYCH TARGOWISK}

Place, na których odbywały się targi, już od wieków, jak wspomniano, stanowiły nieodłączny element struktury miast w Polsce. Na ich pierwotne zagospodarowanie składały się przede wszystkim jatki i kramy kupieckie. Z biegiem czasu ich powierzchnię coraz bardziej zabudowywano, dostosowując ją do zachodzących zmian zarówno w liczbie ludności miasta, jak i ich potrzeb. W rezultacie na rynkach pojawiły się także kantory kupieckie, sukiennice, a nierzadko i ratusz. Współcześnie powierzchnia targowisk nadal ulega przekształceniom, co ma związek m.in. z nieustannym procesem porządkowania miasta, a tym samym i dostosowywania jego przestrzeni do zmieniających się potrzeb mieszkańców. Coraz częściej miejsce boksów, kiosków, straganów przeznaczonych do handlu obwoźnego, znajdujących się na otwartej przestrzeni, zajmują zadaszone i nowoczesne hale targowe. W efekcie zmienia się nie tylko zagospodarowanie targowisk, ale także warunki prowadzenia tego typu handlu.

Zagospodarowanie placu targowego można analizować z różnych punktów widzenia. W niniejszych badaniach przyjęto za M. Gołąb-Korzeniowską (1997), że na zagospodarowanie placu targowego składają się dwa podstawowe elementy: niezbędne urządzenia sanitarne (węzeł sanitarny, miejsce gromadzenia odpadów i poboru wody) oraz elementy zagospodarowania niezbędne do prowadzenia sprzedaży.

Przeprowadzona na wybranych targowiskach inwentaryzacja terenowa ujawniła, że place te cechuje duże podobieństwo pod względem zagospodarowania, co ma głównie związek z podobnym rodzajem oferowanych przez nie funkcji. Jako przestrzenie przeznaczone pod działalność w głównej mierze handlową, nastawioną na obsługę dużej liczby ludności niemal codziennie, wyposażone są w infrastrukturę sanitarną oraz obiekty niezbędne do prowadzenia działalności handlowej. Wszystkie wyposażone są w węzeł sanitarny oraz miejsce służące do gromadzenia niepotrzebnych odpadów. Ponadto ich nawierzchnia wyłożona jest płytami chodnikowymi lub kostką brukową. Cechuje je także podobny udział powierzchni zajętej przez handel. Na każdym 
z wyróżnionych targowisk stanowi ona bowiem nieznacznie ponad 80\% ich powierzchni ogólnej.

Z uwagi na fakt, że wszystkie trzy targowiska przeszły niedawno (w latach 2000-2010) gruntowną modernizację, na każdym z nich działalność handlowa odbywa się przede wszystkim w nowoczesnych halach targowych oraz w mniejszym stopniu na stoiskach niezadaszonych, typu boksy, stragany, kioski. Jeszcze mniej miejsc place te oferują na handel obwoźny i sezonowy - od 5\% (Zielony Rynek) do 10\% (Górniak, Rynek Bałucki) ich ogólnej powierzchni. Taki sposób zagospodarowania tych targowisk, wyznaczony przede wszystkim obecnością dużych i zadaszonych hal targowych, przy jednocześnie małym udziale stoisk i boksów oferujących towary na wolnym powietrzu, jest z jednej strony wyznacznikiem dokonujących się systematycznie na targowiskach zmian w zakresie ich zagospodarowania, ale z drugiej jest też narzucony przez konkurencję wszechobecnych hiper- i supermarketów, które poprzez zadaszenie oferują możliwość wygodnego robienia zakupów niezależnie od warunków pogodowych. „Wygodnictwo społeczeństwa - jak zauważyła A. Pasiut - działa bowiem na niekorzyść otwartych przestrzeni handlowych, a tym samym zmniejsza znaczenie targowisk" (Pasiut, 2012: 446).

Stąd też zarówno na Górniaku, Zielonym Rynku, jak i na Rynku Bałuckim handel odbywa się przede wszystkim w osobnych halach targowych. Różni je tylko liczba oferowanych przez nie miejsc oraz ich rozmieszczenie (lokalizacja) w obrębie powierzchni targowiska (tabela 1).

Tabela 1. Liczba miejsc przeznaczonych na handel na wybranych do badań targowiskach

\begin{tabular}{|l|c|c|c|}
\hline \multicolumn{1}{|c|}{ Nazwa targowiska } & Liczba hal targowych & $\begin{array}{c}\text { Liczba stoisk } \\
\text { zadaszonych }\end{array}$ & $\begin{array}{c}\text { Liczba stoisk } \\
\text { niezadaszonych }\end{array}$ \\
\hline Zielony Rynek & 1 & 146 & 20 \\
\hline Górniak & 2 & 148 & 50 \\
\hline Rynek Bałucki & 2 & 283 & 31 \\
\hline
\end{tabular}

Źródło: opracowanie własne na podstawie inwentaryzacji terenowej

Na obszarze Zielonego Rynku aktualnie funkcjonuje jedna hala targowa, która została oddana do użytku w 2007 roku. Zajmuje ona całą centralną część targowiska i oferuje łącznie 146 miejsc handlowych w postaci zadaszonych boksów, kiosków i straganów. Ponadto wzdłuż ulicy Zielonej znajdują się także boksy przeznaczone wyłącznie do sprzedaży kwiatów.

Na Górniaku funkcjonują z kolei dwa zadaszone obiekty w postaci hali targowej oraz pasażu handlowego. Hala targowa zajmuje centralną i południową część rynku, natomiast pasaż handlowy wypełnia przestrzeń targowiska od strony północnej, zachodniej i południowej. W sumie te dwie hale zajmują ponad 9 tys. mkw. Łącznie obiekty te oferują 148 miejsc do handlowania (64 w hali i $84 \mathrm{w}$ pasażu). Ponadto wzdłuż północnej ściany tego targowiska (od ulicy Sieradzkiej) znajduje się także kilkadziesiąt (50) niezadaszonych stoisk handlowych, natomiast od jego strony południowej plac ma wyznaczone miejsca na handel obwoźny i sezonowy. Aktualny sposób zagospodarowania rynek ten uzyskał w 2009 roku.

Rynek Bałucki, który jest największym detalicznym targowiskiem w województwie łódzkim, również został zmodernizowany w latach 2007-2009 oraz w 2015 roku. Wcześniej, przez długie dziesięciolecia rynek ten należał do najbardziej zaniedbanych 
i chaotycznych pod względem zagospodarowania. Środek placu wypełniały bowiem prowizoryczne stoiska, budy i wiaty. Aktualnie posiada dwie nowoczesne hale targowe - jedną o powierzchni 4,2 tys. mkw., w której mieści się 250 boksów handlowych, oraz drugą, nieco mniejszą, ale równie nowoczesną, która oferuje 17 kiosków, 31 miejsc do handlu obwoźnego oraz 18 straganów. Hale te wypełniają całą przestrzeń tego placu. W przeciwieństwie do pozostałych jako jedyne łódzkie targowisko oferuje także możliwość garażowania samochodów oraz warsztat samochodowy.

\section{SPOŁECZNA I GOSPODARCZA FUNKCJA WSPÓŁCZESNYCH TARGOWISK}

Zgodnie z koncepcją funkcji miejsca funkcja działania wynika z wykonywanej w mieście/miejscu działalności gospodarczej, która jest społecznie użyteczna i zaspokaja bezpośrednio i pośrednio potrzeby ludzi. Z kolei funkcja społeczna (postrzegania i znaczenia) jest społeczną percepcją, czyli subiektywnym postrzeganiem przez człowieka jego form materialnych i przestrzenno-organizacyjnych, a także ich oceną i polega na przypisywaniu percypowanej przez nich przestrzeni określonych znaczeń i wartości.

Identyfikacja funkcji użytkowej na terenie wybranych do badań placów ujawniła, że koncentrują one podobny rodzaj działalności gospodarczej, aczkolwiek różna jest ich struktura. Na badanych targowiskach łącznie zlokalizowanych jest 850 podmiotów gospodarczych. Wśród nich największy udział (95\%) zajmują podmioty reprezentujące sekcje handel detaliczny, pozostałe 5\% przypada natomiast głównie na działalność finansową i ubezpieczeniową, usługi gastronomiczne oraz pozostałą działalność usługową.

Pod szyldami poszczególnych podmiotów gospodarczych najczęściej kryją się: sprzedaż żywności, sprzedaż narzędzi technologii informacyjnej, w tym komputerów i oprogramowania, sprzętów i artykułów gospodarstwa domowego (wyroby tekstylne, metalowe, sprzęt AGD), sprzedaż wyrobów związanych z kulturą, tj. książek, gazet, sprzętu sportowego, gier, zabawek, a także sprzedaż pozostałych wyrobów typu: obuwia, wyrobów skórzanych, wyrobów farmaceutycznych, kwiatów, zegarków, biżuterii.

Choć na pierwszy rzut oka rynki te oferują podobne towary i usługi, w rzeczywistości struktura ich działalności wykazuje pewne różnice (ryciny 1 i 2). Najbardziej zbliżone struktury mają Górniak i Rynek Bałucki. Zarówno na jednym, jak i na drugim wyraźnie dominują podmioty specjalizujące się w sprzedaży pozostałych wyrobów, w tym przede wszystkim obuwia i odzieży, zaś na drugim miejscu - w sprzedaży żywności.

Warto jednak dodać, że o ile na Rynku Bałuckim prym wiodą artykuły ogólnospożywcze i mięso, o tyle na Górniaku jest to głównie sprzedaż artykułów ogólnospożywczych. Badania przeprowadzone na Zielonym Rynku ujawniły z kolei odwrotną tendencję. Wyraźnie bowiem pierwsze skrzypce grają podmioty sprzedające żywność (59,64\%), w tym głównie o profilu ogólnospożywczym i warzywnym (owoce i warzywa), oraz pieczywo $(59,64 \%)$, natomiast na drugim miejscu są podmioty oferujące pozostałe produkty $(31,07 \%)$, w tym głównie odzież i kosmetyki. Co ciekawe, wszystkie place cechuje podobny udział punktów oferujących napoje alkoholowe, tj. nie więcej niż 1,5\%. Udział pozostałych działalności, pozahandlowych, jest stosunkowo niewielki. Na targowisku Górniak stanowią one zaledwie 2,5\% ogółu podmiotów, natomiast na Zielonym Rynku i na Rynku Bałuckim - po niecałym 1\%. Wśród nich najczęściej występują usługi krawiecko-kuśnierskie, kserograficzne, fryzjerskie i kosmetyczne. 
Rycina 1. Struktura działalności gospodarczej w zakresie sprzedaży żywności i pozostałych usług na wybranych targowiskach w 2019 roku

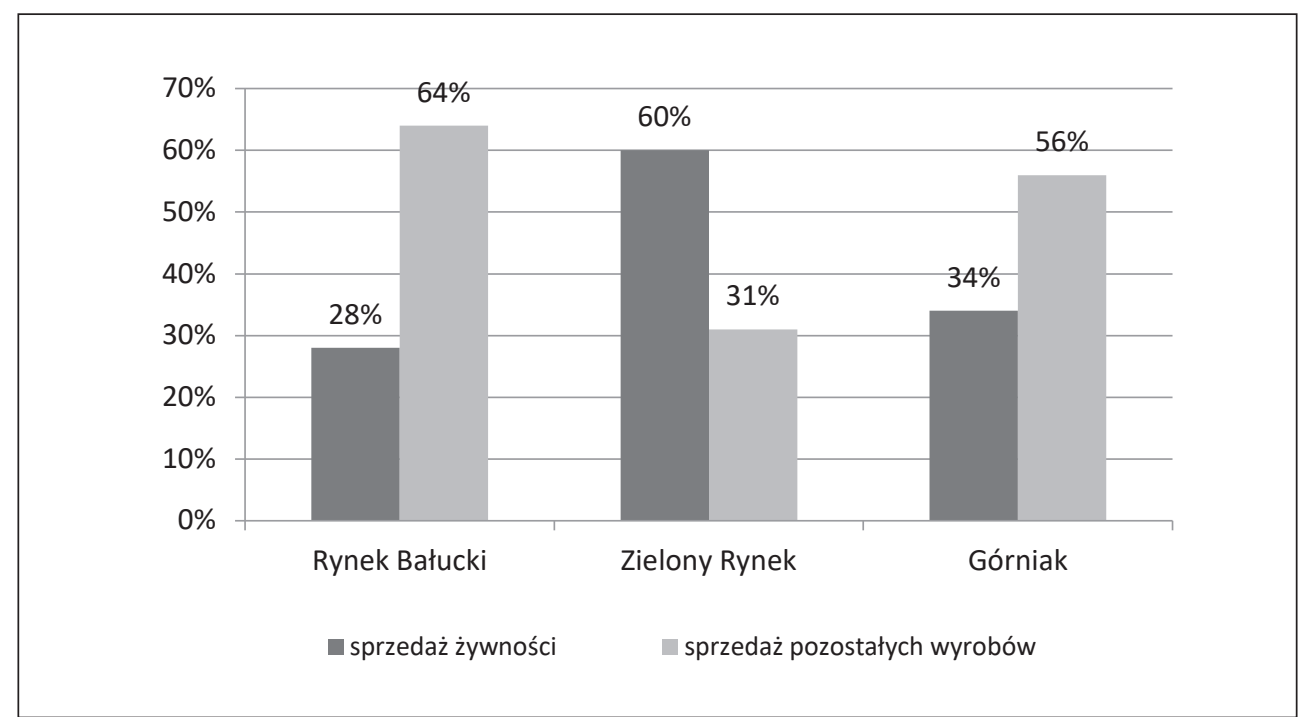

Źródło: opracowanie własne na podstawie inwentaryzacji terenowej

Rycina 2. Struktura pozostałej działalności gospodarczej na wybranych targowiskach w 2019 roku

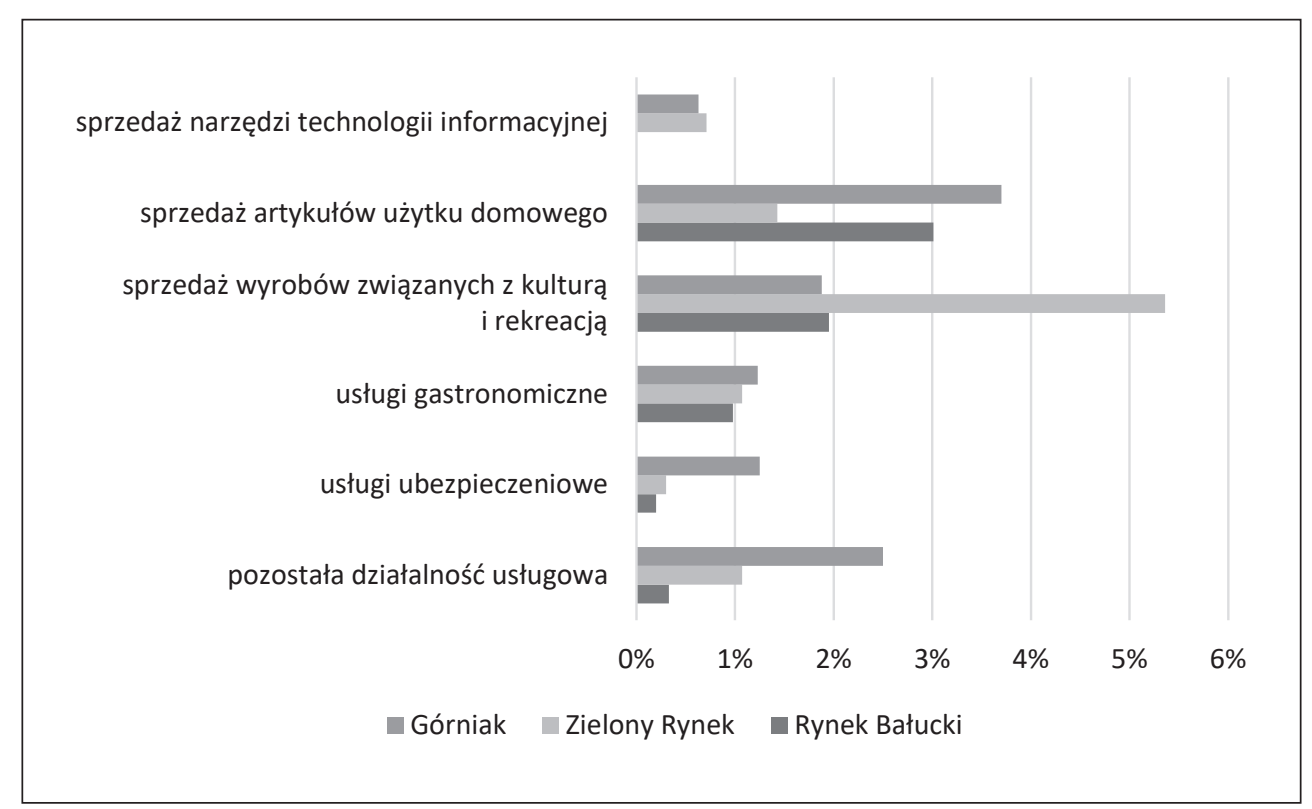

Źródło: opracowanie własne na podstawie inwentaryzacji terenowej

W celu dokładniejszego zaprezentowania funkcji gospodarczej wybranych placów dokonano ich podziału w obrębie sekcji sprzedaży żywności, dzieląc je na: sprzedaż prowadzoną w sklepach z przewagą żywności, owoców i warzyw, mięsa, ryb, pieczywa i wyrobów cukierniczych oraz napojów alkoholowych (rycina 3). 
Rycina 3. Struktura handlu artykułami spożywczymi na wybranych targowiskach w 2019 roku

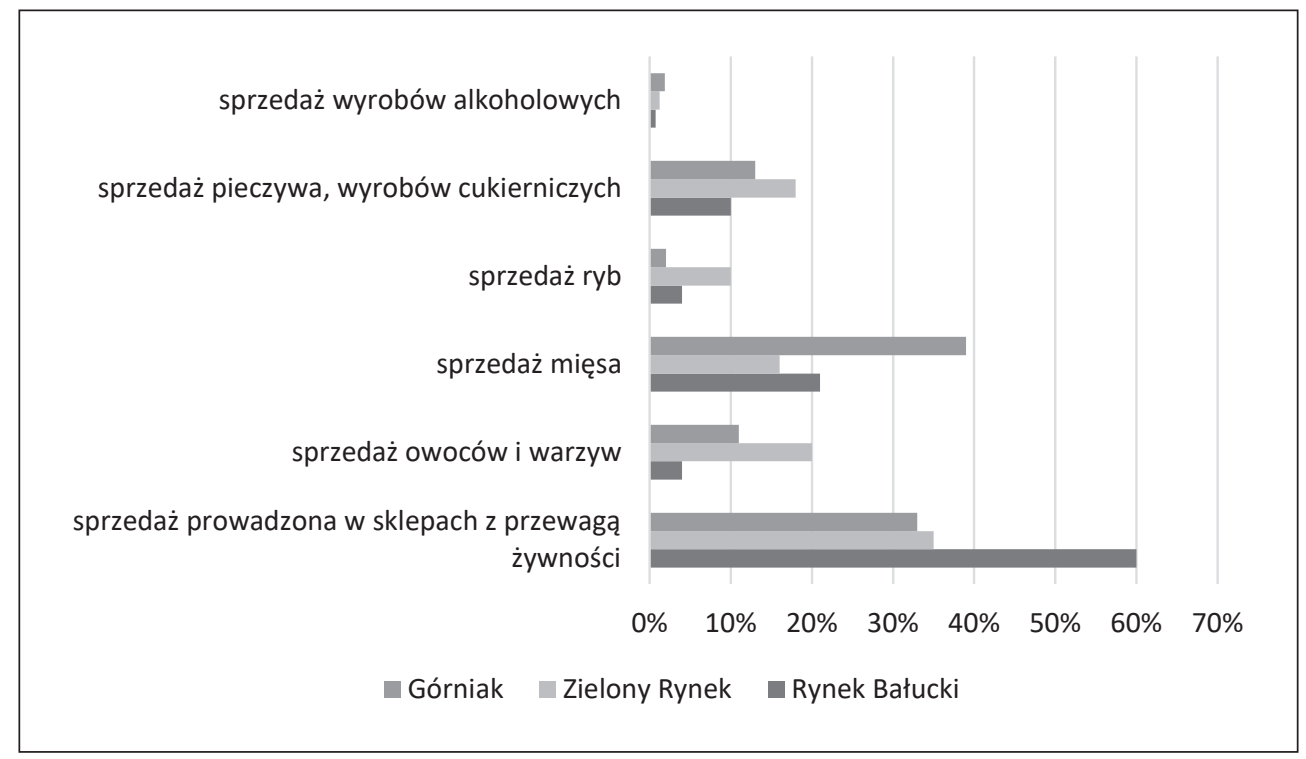

Źródło: opracowanie własne na podstawie inwentaryzacji terenowej

W efekcie badania ujawniły, że Rynek Bałucki cechuje wyraźna specjalizacja w zakresie sprzedaży towarów ogólnospożywczych, na które przypada ponad 60\% ogółu zlokalizowanych tam podmiotów handlowych, Górniak wyróżnia z kolei przewaga sklepów mięsnych $(38,89 \%)$, choć podobny udział zajmują tu sklepy ogólnospożywcze (33,33\%), natomiast Zielony Rynek cechuje najbardziej wyrównana struktura w zakresie występowania wyróżnionych kategorii artykułów spożywczych, niemniej nieznaczną dominację wykazują sklepy ogólnospożywcze (35,33\%).

Identyfikacja sposobu użytkowania wybranych do badań placów targowych jest bardzo ważnym etapem w poznaniu funkcji tych miejsc. Niemniej jednak, aby w pełni odpowiedzieć na postawione we wstępie artykułu pytanie, czy targowiska są nam jeszcze potrzebne, konieczna jest identyfikacja ich funkcji społecznej. Z uwagi na fakt, iż funkcja społeczna jest bardzo szerokim zagadnieniem, w artykule skupiono się na zbadaniu znaczenia tych przestrzeni dla mieszkańców Łodzi, w tym szczególnie poruszono zagadnienia dotyczące m.in.: znajomości historii tych miejsc, częstotliwości i celu ich odwiedzin, stosunku emocjonalnego oraz oceny ich funkcjonowania.

Wszystkie wybrane do badań targowiska z uwagi na swoje długie tradycje handlowe są dobrze znane łodzianom. Badani bezbłędnie potrafili wskazać ich lokalizację, a co czwarty z nich zadeklarował także znajomość podstawowych faktów z ich historii, w tym bezbłędnie podał okres ich założenia. Źródłem tej wiedzy, jak deklarowali ankietowani, najczęściej były wspomnienia i opowieści starszych członków rodziny o tych placach, co wskazuje, że miejsca te od zawsze stanowiły znaczącą i rozpoznawalną przestrzeń w mieście, a tym samym są mocno zakorzenione w świadomości badanych mieszkańców.

Targowiska te są także wśród badanych bardzo popularnym miejscem robienia codziennych zakupów, dużo popularniejszym niż tradycyjne markety czy dyskonty. W odpowiedzi na pytanie: „Gdzie częściej dokonuje Pan/Pani codziennych zakupów - 
na targowisku czy w sklepie typu market, dyskont?" respondenci znacznie częściej wskazywali te pierwsze (65\%), motywując to głównie możliwością zakupu dużo świeższych warzyw i owoców, bliskością tej formy handlu, czyli możliwością dotarcia tam bez konieczności korzystania z samochodu oraz, co ciekawe, dużo większym asortymentem po niższej cenie. Ponadto respondentów do korzystania z tej formy handlu przyciąga także przyzwyczajenie i wygoda. Dość często respondenci wskazywali, że chodzą na targowisko, bo mają tam swoich zaprzyjaźnionych sprzedawców, u których zaopatrują się w towar już od lat. 0 ich wyborze decyduje zatem nie tylko przyzwyczajenie, ale również zaufanie, jakim darzą sprzedających.

Co ciekawe, pytanie o częstotliwość korzystania z tej formy handlu ujawniło, że ponad połowa (62\%) respondentów zakupy na targowisku robi co najmniej trzy razy w tygodniu, a kolejne $23 \%$ co najmniej raz w tygodniu. W przypadku marketu/dyskontu respondenci zadeklarowali odwrotnie proporcje odpowiedzi, co raz jeszcze dowodzi przewagi robienia codziennych zakupów na targowiskach nad marketami. Badane targowiska są miejscem, gdzie respondenci dokonują bardzo różnych zakupów, ale najczęściej zaopatrują się tam w żywność (74\%), w tym głównie w warzywa, owoce, jaja i mięso, ponadto odzież (41\%) i szeroko rozumianą chemię (25\%).

Wielu respondentów zadeklarowało także, że na targowisku najczęściej kupuje papierosy, miód oraz chleb. Są to produkty, które w takiej cenie i jakości, zdaniem badanych, trudno kupić w sklepie. Chodzi tu szczególnie o miód, który na każdym z tych rynków oferowany jest prosto od producenta. Warto dodać, że szczególnie Rynek Bałucki przyciąga klientów czymś jeszcze, a mianowicie starociami, które od lat można tu nabyć w określone dni. Organizowana tu raz w tygodniu sprzedaż staroci jest wyjątkową gratką dla koneserów starych i wartościowych przedmiotów, dlatego też wśród wymienionych powodów nie zabrakło i tego. Pod tym względem jest to szczególne targowisko, porównywane z tym w Kazimierzu Dolnym czy z Jarmarkiem Dominikańskim w Gdańsku.

Badani zostali także poproszeni o ocenę funkcjonowania wybranych targowisk pod względem niektórych cech (tabela 2). Oceniali targowiska w skali od 1 do 5, gdzie 1 oznaczało ocenę najniższą, a 5 - najwyższą Wyniki badania ujawniły, że respondenci bardzo pozytywnie oceniają łódzkie targowiska. Wszystkie z wyróżnionych w ankiecie kategorii uzyskały bowiem średnią ocenę powyżej 4. Najwyżej ocenione zostały jakość produktów $(4,65$, ponad $50 \%$ ocen pozytywnych) oraz ich wybór $(4,50,48 \%$ ocen pozytywnych). Ponadto respondenci bardzo dobrze oceniają obsługę klientów, co tym samym potwierdza, że targowisko jest miejscem przyjaznym do robienia zakupów. Miejscem, gdzie można, jak podkreślają niektórzy autorzy, dokładnie obejrzeć towar, ale i bezpośrednio wynegocjować jego cenę.

Tabela 2. Funkcjonowanie targowisk - ocena respondentów

\begin{tabular}{|l|c|}
\hline \multicolumn{1}{|c|}{ Cechy targowisk } & Średnia ocena \\
\hline Obsługa klienta & 4,43 \\
\hline Wybór produktów & 4,50 \\
\hline Poziom cen & 4,32 \\
\hline Jakość produktów & 4,65 \\
\hline Godziny otwarcia & 4,10 \\
\hline Formy płatności & 4,15 \\
\hline
\end{tabular}

Źródło: opracowanie własne na podstawie badań ankietowych 
O tym, że targowiska zajmują ważne miejsce w świadomości badanych mieszkańców, świadczy także fakt, że dostrzegają oni zachodzące na ich obszarze zmiany, w tym głównie modernizację hal targowych i sposobu ich zagospodarowania, ale i plany Urzędu Miasta co do przyszłości jednego z nich. Pomimo iż ankieta nie zawierała pytania dotyczącego stosunku respondentów do planowanej przez Urząd Miasta likwidacji rynku na placu Barlickiego, to ponad 70\% respondentów, spontanicznie, przy okazji, wyraziło swoje głębokie niezadowolenie z tego pomysłu. Z jednej strony wskazuje to zatem na ogromne zainteresowanie respondentów losem i przyszłością tego miejsca, z drugiej na potrzebę kontynuowania w tym miejscu funkcji handlowej.

To, że miejsca te nie są obojętne badanym, a tym samym mają dla nich pewną wartość, ujawniło także pytanie dotyczące ich stosunku emocjonalnego do tych targowisk. W przypadku żadnego z nich respondenci nie zadeklarowali dostępnej w ankiecie opcji: „nie lubię tego miejsca”, za to blisko 60\% ankietowanych zadeklarowało, że je lubi. I choć powodów, dla których ankietowani darzą te miejsca sympatią, jest wiele, to tymi najczęściej powtarzanymi były głównie sympatia do robienia tam zakupów oraz sprzedających tam kupców.

Więc czy targowiska są nam jeszcze potrzebne? Badani raczej nie wyobrażają sobie Łodzi bez tych targowisk, o czym świadczy ich odpowiedź na tak zadane pytanie. Wśród badanych nie było bowiem osoby, która zadeklarowała opcję „nie”.

\section{ZAKOŃCZENIE}

Czy place targowe są nam, mieszkańcom współczesnych miast, jeszcze potrzebne? W świetle badań własnych można pozytywnie zweryfikować postawioną na wstępie tezę. Choć rola targowisk w życiu współczesnego miasta wciąż ewoluuje i nie brakuje opinii, że czas targowisk w formie, w jakiej funkcjonują one od lat, się kończy, nie można jednak jednoznacznie powiedzieć, że straciły one swoją funkcję. Wciąż bowiem, jak dowiodły tego przeprowadzone badania, są przede wszystkim miejscem dokonywania zakupów, ale i miejscem spotkań, przyjaznym drugiemu człowiekowi. Można nawet zaryzykować stwierdzenie, że poprzez fakt, że ludzie przebywają w nich nawet codziennie, pełnią swoistą funkcję kulturotwórczą, są zatem też elementem silnie identyfikującym mieszkańców z miastem.

Wprawdzie podjęte badania nie koncentrowały się na zagadnieniu tożsamości tych miejsc dla mieszkańców, ale z uzyskanych na podstawie ankiet wypowiedzi można wywnioskować, że są one dla badanych miejscem znaczącym i to nie tylko z racji robienia tam codziennych zakupów. Wciąż są jeszcze przez mieszkańców odwiedzane. I sądząc po wypowiedziach respondentów, pewnie jeszcze długo będą, bo żaden z nich nie zadeklarował chęci ich likwidacji. Więc raczej należy przyznać rację tym badaczom, którzy tak jak w przypadku przestrzeni publicznych, wieszczą nie ich kryzys, lecz nowy etap rozwoju, dostosowany do nowych potrzeb społecznych. Może już niedługo z naszego krajobrazu zupełnie znikną targowiska w tradycyjnym rozumieniu, gdzie zakupy robi się na świeżym powietrzu, krążąc między stoiskami, gawędząc ze sprzedającymi, oferującymi przy okazji możliwość spróbowania swojego towaru, ale na pewno jeszcze długo nie zniknie potrzeba zakupu w tej tradycyjnej, swojskiej aurze, której nie oferują hipermarkety. Dowodem na to, że ich czas się jeszcze nie skończył, mogą być obserwowane ostatnio w Łodzi protesty mieszkańców przeciwko decyzji Urzędu Miasta o likwidacji jednego z badanych rynków. 


\section{Literatura \\ References}

Baranowski, B., Fijałek, J., Rosin, R. (1988). Łódź. Dzieje miasta. Tom I do 1918 roku. Łódź: Polskie Wydawnictwo Naukowe.

Barek, R., (2010). Targowisko - przestrzeń niezbędna w środowisku zamieszkania, Czasopismo Techniczne, Architektura, 107(5), 9-14.

Bierwiaczonek, K., Lewicka, B., Nawrocki, T. (2012). Rynki, malle i cmentarze. Przestrzeń publiczna miast ślq̨skich $w$ ujęciu socjologicznym. Katowice: Wyd. NOMOS, Uniwersytet Śląski w Katowicach.

Bieszk-Stolorz, B., Felsztyńska, I. (2018). Analiza atrakcyjności dużych miast pod względem rozwoju handlu targowiskowego. Studia i Prace Wydziału Nauk Ekonomicznych i Zarządzania Uniwersytetu Szczecińskiego, 54(3), 408-419.

Ciechomski, W. (2014). Handel targowiskowy w Poznaniu - diagnoza stanu rozwoju, preferencje klientów, tendencje zmian. Zeszyty Naukowe Wyższej Szkoły Handlu i Usług w Poznaniu, 28, $25-46$.

Derek, M. (2014). Miejska przestrzeń czasu wolnego. W: M. Madurowicz (red.). Kształtowanie współczesnej przestrzeni miejskiej. Warszawa: Wyd. Uniwersytetu Warszawskiego, 210-217.

Dziechciarz, T. (1992a). Zróżnicowanie cen na placach targowych miasta Krakowa. Prace Instytutu Geografii Uniwersytetu Jagiellońskiego, Prace Geograficzne, 91.

Dziechciarz, T. (1992b). Funkcjonowanie handlu na placach targowych na przykładzie placu Nowego w Krakowie. Folia Geographica, Series Geographica-Oeconomica, XXV-XXVI, 81-91.

Gołąb-Korzeniowska, M. (1997). Rola i znaczenie placów handlowych $w$ strukturze przestrzennej miasta na przykładzie Krakowa. Kraków: Biblioteka Cyfrowa Politechniki Krakowskiej.

Hamulczuk, M. (2016). Terytorialne zróżnicowanie handlu targowiskowego w Polsce i jego uwarunkowania. Handel Wewnętrzny, 369, 92-102.

Koter, M. (1969). Geneza układu przestrzennego Łodzi przemysłowej, Warszawa: PWN.

Kowalczyński, K.R., (2008). Łódź przełomu wieków XIX/XX. Łódź: Księży Młyn Dom Wydawniczy.

Kulesza, M., Pawłowski, M. (1985). Bałuty 1430-1915. Komitet Dzielnicowy PZPR Łódź-Bałuty. Łódź: Wydawnictwo Historii Miasta Łodzi.

Lautor, S. (1995). Rynek i plac miejski w starych miastach Pomorza Zachodniego - przeszłość i teraźniejszość. Urbanistyka. Międzyuczelniane Zeszyty Naukowe, I.

Liszewski, S., Maik, W. (2000). Wielka encyklopedia geografii świata, tom XIX, Osadnictwo. Poznań: Wyd. Kurpisz.

Malinowska, M. (2016). Targowiska w Polsce - schyłek, czy rozkwit? Studia Ekonomiczne. Zeszyty Naukowe Uniwersytetu Ekonomicznego w Katowicach, 302.

Mydel, R. (1977). Place targowe współczesnego Krakowa. Zeszyty Naukowe Uniwersytetu Jagiellońskiego. Prace Geograficzne, 44.

Pasiut, A. (2012). Targowisko we współczesnym mieście - w poszukiwaniu formy. Przestrzeń i Forma, 17, 445-456.

Płaziak, M., Szymańska, A. (2014). Rola placów targowych w strukturze przestrzenno-społecznej i ekonomicznej Nowej Huty. W: E. Kaczmarska, P. Raźniak. (red.). Społeczno-ekonomiczne i przestrzenne przemiany struktur regionalnych. Kraków: Oficyna Wydawnicza AFM.

Płaziak, M., Szymańska, A. (2015). Uwarunkowania działalności przedsiębiorców i rolników na placach targowych na przykładzie Nowej Huty. Przedsiębiorczość-Edukacja, 11, 203-217.

Płaziak, M., Szymańska, A. (2016a). Czynniki warunkujące atrakcyjność dokonywania zakupów na placach targowych Krakowa. Przedsiębiorczość-Edukacja, 12, 217-231.

Płaziak, M., Szymańska, A. (2016b). Uwarunkowania zachowań konsumentów na placach targowych na przykładzie Nowej Huty. Studia Ekonomiczne, 255, 186-199.

Powęska, H. (2002a). Przestrzenny wymiar handlu targowiskowego w województwie małopolskim w 2000 roku. W: Z. Górka, A. Jelonek. (red.). Geograficzne uwarunkowania rozwoju Małopolski. Kraków: Instytut Geografii i Gospodarki Przestrzennej. Wyd. Uniwersytetu Jagiellońskiego, 413-416.

Powęska, H. (2002b). Przestrzenny wymiar handlu transgranicznego w Polsce w ostatniej dekadzie XX wieku. Geopolitical Studies, 9. Warszawa: Wydawnictwa Instytutu Geografii i Przestrzennego Zagospodarowania Polskiej Akademii Nauk.

Przesmycka, E. (2008). Serce współczesnego miasta. Czasopismo Techniczne, 4-A, 77-87. 
Sławińska, M., (2014). Przemiany strukturalne w handlu detalicznym Poznania. Zeszyty Naukowe Wyższej Szkoły Handlu i Usług w Poznaniu, 28, 13-24.

Sojkin, B., Michalak, S. (2018). Targowisko jako miejsce zakupów mieszkańców dużych miast. Handel Wewnętrzny, 4(375), t. 1, 327-339.

Spodenkiewicz, P. (1999). Zaginiona dzielnica. Łódź żydowska - ludzie, miejsca. Łódź: Łódzka Księgarnia Niezależna.

Suliborski, A. (2001). Funkcje i struktura funkcjonalna miast. Studia empiryczno-teoretyczne. Łódź: Wydawnictwo Uniwersytetu Łódzkiego.

Suliborski, A. (2010). Funkcjonalizm w polskiej geografii miast. Studia nad genezq i pojęciem funkcji. Łódź: Wydawnictwo Uniwersytetu Łódzkiego.

Suliborski, A., Wójcik, M. (2014). Geografia społeczna w Polsce - geneza, koncepcje i zróżnicowanie problemowe, ze szczególnym uwzględnieniem studiów geograficzno-miejskich w ośrodku łódzkim. W: A. Suliborski, M. Wójcik (red.). Dysproporcje społeczne i gospodarcze w przestrzeni Łodzi. Czynniki, mechanizmy, skutki. Łódź: Wydawnictwo Uniwersytetu Łódzkiego, 7-17.

Szromik, A. (2014). Targi w gospodarce rynkowej. Kraków-Legionowo: Wyd. Edu-Libri.

Tomalak, M., Wyżnikiewicz, B. (1999). Handel targowiskowy w 1998 roku. Warszawa: Instytut Badań nad Gospodarka Rynkową.

Urban, S., Michałowska, M. (2013). Czynniki wpływające na zachowania konsumentów w zakresie wyboru targowisk jako miejsca zakupu produktów konsumpcyjnych na przykładzie województwa lubuskiego. Roczniki Ekonomiki Rolnictwa i Rozwoju Obszarów Wiejskich, 100(2), 108-118.

Urząd Miasta Łódź (2019, 12 września). Konkurs architektoniczno-urbanistyczny. Pozyskano z https://uml.lodz.pl/aktualnosci/artykul/zielony-rynek-konkurs-architektoniczno-urbanistyczny-id29733/2019/8/9/

Werwicki, A. (2001). Handel targowiskowy aglomeracji łódzkiej na tle jego znaczenia ogólnopolskiego w latach 1994-1997. Łódź: Łódzkie Towarzystwo Naukowe.

Wojdacki, K.P. (2011). Przestrzenne aspekty rozwoju handlu targowiskowego w Polsce. Handel Wewnętrzny, 6, 23-35.

Wojdacki, K.P. (2016). Terytorialne zróżnicowanie handlu targowiskowego w Polsce - analiza statystyczna. Problemy Zarządzania, 14(1)(57), 212-231.

Zuzańska-Żyśko, E., Sitek, S. (2011). Rola handlu targowiskowego w rozwoju miast. W: M. Soja, A. Zborowski (red.). Człowiek w przestrzeni zurbanizowanej. Kraków: Instytut Geografii i Gospodarki Przestrzennej Uniwersytetu Jagiellońskiego, 271-281.

Anita Kulawiak, dr, Uniwersytet Łódzki, Wydział Nauk Geograficznych, Katedra Geografii Regionalnej i Społecznej, dr nauk o Ziemi, adiunkt w Katedrze Geografii Regionalnej i Społecznej UŁ. Zainteresowania badawcze autorki koncentrują się na zagadnieniach związanych z szeroko rozumianą kwestią miejską oraz problemami społecznymi i gospodarczymi miasta. W szczególności w dotychczasowym dorobku badawczym autorki znalazły się prace poświęcone kreowaniu i rozwojowi przedsiębiorczości na obszarze miast, w tym wpływowi władz lokalnych i funduszy unijnych na jej rozwój, zmianom i współczesnej tożsamości przestrzeni publicznych oraz funkcjom gospodarczym i społecznym miast. Autorka i współautorka ponad 40 artykułów naukowych.

Anita Kulawiak, PhD, University of Lodz, Faculty of Geographical Sciences, Department of Regional and Social Geography. PhD in Geography, assistant professor in the Department of Regional and Social Geography at the University of Lodz. The author's research interests focus on issues related to the broadly understood urban issue and its social and economic problems. In particular, the author's research to date includes works devoted to the creation and development of entrepreneurship in cities, including the impact of local authorities and EU funds on its development, changes and contemporary identity of public spaces, as well as the economic and social functions of cities. Author and co-author of over 40 articles.

ORCID: https://orcid.org/0000-0002-1194-837X

\title{
Adres/address:
}

\author{
Uniwersytet Łódzki \\ Wydział Nauk Geograficznych \\ Katedra Geografii Regionalnej i Społecznej \\ ul. Kopcińskiego 31, 90-142 Łódź, Polska \\ e-mail: anita.kulawiak@geo.uni.lodz.pl
}

